\title{
Long-term increase of phytoplankton biomass in Chesapeake Bay, 1950-1994*
}

\author{
L. W. Harding Jr' ${ }^{1, * *}$, E. S. Perry ${ }^{3}$ \\ 'Maryland Sea Grant College, University System of Maryland, 0112 Skinner Hall, College Park, Maryland 20742, USA \\ ${ }^{2}$ Horn Point Laboratory, University of Maryland Center for Environmental Science, Box 775, Cambridge, Maryland 21613, USA \\ ${ }^{3} 2000$ Kings Landing Road, Huntingtown, Maryland 20639, USA
}

\begin{abstract}
An analysis of historical and recent data on chlorophyll a for Chesapeake Bay reveals that a significant increase of phytoplankton biomass has occurred during the last 40 to $50 \mathrm{yr}$. Concentrations of chlorophyll $a$ in the surface mixing layer have increased 5- to 10 -fold in the seaward regions of the estuary and 1.5- to 2-fold elsewhere, paralleling published estimates of increased loading of $\mathrm{N}$ and $\mathrm{P}$ to the estuary since World War II. The characteristic high variability of freshwater flow that occurs on seasonal to interannual time scales, however, drives fluctuations of chlorophyll a that are superimposed on this apparent upward trend, potentially obscuring the effects of overenrichment on chlorophyll $a$ concentrations in nutrient-limited regions of the Bay. To resolve a time trend of chlorophyll from this variability, we developed regional models of mean, monthly chlorophyll a using autoregressive moving average (ARMA) procedures. The models were developed with water quality data from monitoring cruises of the Chesapeake Bay Program spanning 1984 to 1992. The approach was to: (1) determine the relationship of prominent variables, including freshwater flow, salinity, temperature, region, and time of year, to chlorophyll a for the 'modern' Bay; (2) predict chlorophyll a for the 'historical' Bay based on these models and actual, observed variables for periods from 1950 to 1984 for which chlorophyll $a$ data were available; (3) compare chlorophyll a predicted from modern relationships, to those observed in the past, using the residuals to identify deviations below or above expected concentrations that would suggest an effect on chlorophyll a unrelated to flow variability. The results show that: (1) observed and predicted chlorophyll a concentrations matched reasonably well for the years that were used to develop the models, with some exceptions when the models failed to capture extremely high concentrations of chlorophyll a during blooms; (2) chlorophyll a concentrations in the 1950s, 1960s, and 1970s were predominantly lower than predicted by the models, particularly in the mesohaline and polyhaline regions of the estuary that are most susceptible to nutrient limitation; (3) chlorophyll a concentrations were lower in the 1960s than in the 1970s, probably as the result of low flow and a concomitant reduction of nutrient loading in the 'dry' 1960s as compared to the 'wet' 1970s; (4) interannual variability was high for both observed and predicted chlorophyll a concentrations in the 1970 s, and this variability was most strongly expressed in the mesohaline to polyhaline Bay, reflecting the spatial and temporal heterogeneity of phytoplankton that prevailed in that period. These findings support the hypothesis that a significant increase of chlorophyll a has occurred in the lower Bay that cannot be accounted for by variability of freshwater flow and attendant properties.
\end{abstract}

KEY WORDS: Phytoplankton biomass - Historical trends Eutrophication Estuaries Chesapeake Bay

\section{INTRODUCTION}

Estuaries and coastal waters are highly productive ecosystems that support important recreational and

\footnotetext{
- Data available via anonymous $\mathrm{ftp}$ at $\mathrm{ftp}: / / \mathrm{ftp}$.mdsg.umd.edu/pub/his_chl

-.E-mail: larry@kestrel.umd.edu
}

commercial fisheries (cf. Houde \& Rutherford 1993, Cloern 1996). Water quality has declined significantly in these systems in recent years, however, driven by human population growth and changes in land use that together have increased nutrient loads (Nixon \& Pilson 1983, Nixon et al. 1986). Chesapeake Bay has historically been the most productive estuary in the US in yields of oysters, crabs, clams and finfish, as 
described in the popular treatise by Horton \& Eichbaum (1991). Deforestation and expanded agriculture in the 18th and 19th centuries led to increases of nitrogen $(N)$ and phosphorus $(P)$ in runoff, and inputs from sewage, animal wastes, fertilizers and atmospheric deposition have continued to increase in the postWorld War II period (Boynton et al, 1995). While the Bay's richness is related to high nutrient inputs and enhanced primary production (Boynton et al. 1982 Kemp \& Boynton 1984), it is widely accepted that current loads of nutrients are excessive and have resulted in a degradation of water quality and the loss of habitat for living resources (cf. Carpenter et al. 1969, D'Elia 1987, Malone 1992).

One of the most serious water quality problems associated with overenrichment by nutrients is the depletion of dissolved oxygen in waters beneath the stable density discontinuity (pycnocline) during spring and summer (Taft et al. 1980, Officer et al. 1984, Seliger et al. 1985). Low dissolved oxygen was first reported in the Bay nearly 60 yr ago (Newcombe \& Horne 1938), and geochemical analyses of benthic sediment cores suggest that hypoxia has occurred periodically for centuries (Cooper \& Brush 1991). The Bay has a natural propensity for $\mathrm{O}_{2}$ depletion because of its basin morphometry and estuarine circulation; these characteristics promote high rates of primary productivity, retention of organic matter, and regeneration of nutrients, while freshwater input ensures strong seasonal stratification and restricts the reaeration of bottom waters (Boicourt 1992, Malone 1992). Stimulation of phytoplankton growth beyond the Bay's assimilation capacity by excess nutrients, however, has caused a worsening of $\mathrm{O}_{2}$ depletion since the 1950s, culminating in the widespread occurrence of anoxia in deep waters each year (summary: Harding et al. 1992b).

Signs of deterioration in the health of Chesapeake Bay, most notably $\mathrm{O}_{2}$ depletion, led to a series of water quality studies between 1950 and 1980. In 1976, the US Environmental Protection Agency (EPA) established the Chesapeake Bay Program (CBP) and detailed studies of the Bay were undertaken over the ensuing $7 \mathrm{yr}$. This work culminated in a series of reports issued in 1983 that subsequently led to a call for significant reductions of $N$ and $P$ inputs to reverse eutrophication of the Bay. The governors of the states of Maryland. Pennsylvania and Virginia, the mayor of the District of Columbia, and the Administrator of the US EPA signed agreements to coordinate Chesapeake Bay cleanup efforts. A Bay-wide monitoring program consisting of regular cruises to sample the water and biota commenced in mid-1984 and continues to this date. Signatories of the 1983 agreement reiterated their commitment in 1987 by pledging their jurisdictions to reduce $\mathrm{N}$ and $\mathrm{P}$ inputs to the Bay $40 \%$ by the year 2000 .
The need to accomplish $\mathrm{N}$ and $\mathrm{P}$ reductions in Chesapeake Bay is apparent, but the outcome remains uncertain, largely because we lack strong quantitative evidence of how the Bay has changed since the early 1950 s and thus lack a context to gauge success in reversing eutrophication. The crux of the problem is that spatial and temporal coverage for prospective indicators of water quality, such as data on chlorophyll a and nutrient concentrations, was very limited for the period prior to 1980. The sparseness of data made it impossible to take into account seasonal and interannual variability and to correct for the effects of predominant influences on this variability, such as prevailing meteorological conditions in the Bay's watershed. Without accounting for variability that occurs on relatively short time-scales, we could not resolve a longterm trend with statistical confidence and thus infer the magnitude of eutrophication-induced changes in the ecosystem

This problem-detecting a trend-is neither new nor unique to Chesapeake Bay, but it is certainly the most vexing issue facing those who seek to improve the Bay's water quality by reducing nutrient inputs. In referring to the Chesapeake's extraordinary variability, Horton \& Eichbaum in: 'Turning the Tide-Saving the Chesapeake Bay' described the Bay as an 'unruly beast', and likened attempts of scientists to 'chart trends in the Bay's health' to sorting out 'an announcer's message from static on the radio' (Horton \& Eichbaum 1991). This colorful analogy is apt because in Chesapeake Bay, as in many other estuarine and coastal systems, detecting changes in water quality over periods of years to decades is complicated by high variability. Few data sets are available with the time span of coverage or the consistency of methodology to permit 'sorting out' the signals of change, particularly for water quality indicators of overenrichment. But beginning just after World War II, data on some properties were collected for Chesapeake Bay, including chlorophyll a concentrations, using methods that are the same as those in place today. Thus, we have data for nearly 5 decades on this important measure of phytoplankton biomass that, although not optimally distributed in time and space as they come from a variety of projects with different aims, represent potentially informative indicators of ecosystem change for this important system.

In this paper, we present quantitative evidence of change in Chesapeake Bay by reporting a long-term increase of phytoplankton biomass, measured as surface chlorophyll a concentrations. Chlorophyll $a$ is a useful expression of phytoplankton biomass and is arguably the single most responsive indicator of $N$ and $P$ enrichment in this system (cf. Harding 1994). The focus of our analysis was to remove the effects of 
freshwater flow and attendant properties by developing regional models to predict chlorophyll a from physical variables, and to use the models to resolve an historical increase of chlorophyll a from variability. Our emphasis on freshwater flow was based on its role in regulating phytoplankton dynamics in this and other estuarine and coastal systems (San Francisco Bay: Cloern et al. 1983, Cole \& Cloern 1984; Delaware Bay: Pennock 1985, Pennock \& Sharp 1986, Sharp et al. 1986; Chesapeake Bay: Malone et al. 1988, 1996. Harding 1994; Hudson River: Malone 1977, Malone \& Chervin 1979; northern Adriatic Sea: Gilmartin et al. 1990, Justic' et al. 1993, 1995; northern Gulf of Mexico: Turner \& Rabalais 1991, 1994). This study represents an extension of an earlier analysis of long-term trends of chlorophyll a in Chesapeake Bay (Harding 1994). The models we developed to quantify a long-term chlorophyll a trend, like any modeling effort, entail simplification of the processes controlling the variable(s) to be predicted. Given limitations of the available data with respect to historical coverage in time and space, however, we have endeavored to create simple models to test the hypothesis that long-term trends in chlorophyll a can be explained by natural variability rather than anthropogenic influences and, in so doing, to separate an increase of chlorophyll a caused by eutrophication from higher frequency signals that are driven by seasonal and interannual patterns of freshwater flow.

\section{METHODS}

The analysis we describe spans 1950 to 1994 and relies on models of mean, monthly chlorophyll a for 6 regions of the Bay (Fig. 1). Data on freshwater flow for the major rivers feeding into Chesapeake Bay were provided by the US Geological Survey. Hydrographic, chlorophyll $a$ and nutrient data were obtained from the historical archive of the CBP that includes results of studies conducted by the Chesapeake Bay Institute (1950-79), data collected on a variety of cruises aboard the RV 'Cape Hatteras', 'Ridgely Warfield' and 'Cape Henlopen' (1982-88), and monitoring data from the CBP-sponsored programs of Maryland and Virginia (1984-present)

Several methods were used to determine chlorophyll a in the different studies represented in the historical archive, and data obtained with similar methods were used whenever possible. We ascertained the methods used for each data set prior to using specific observations in this analysis by examining the data glossary that accompanies the CBP data archive. Most of the data are from measurements made on acetone extracts (80 to $90 \%$ ) of particulate material collected by low

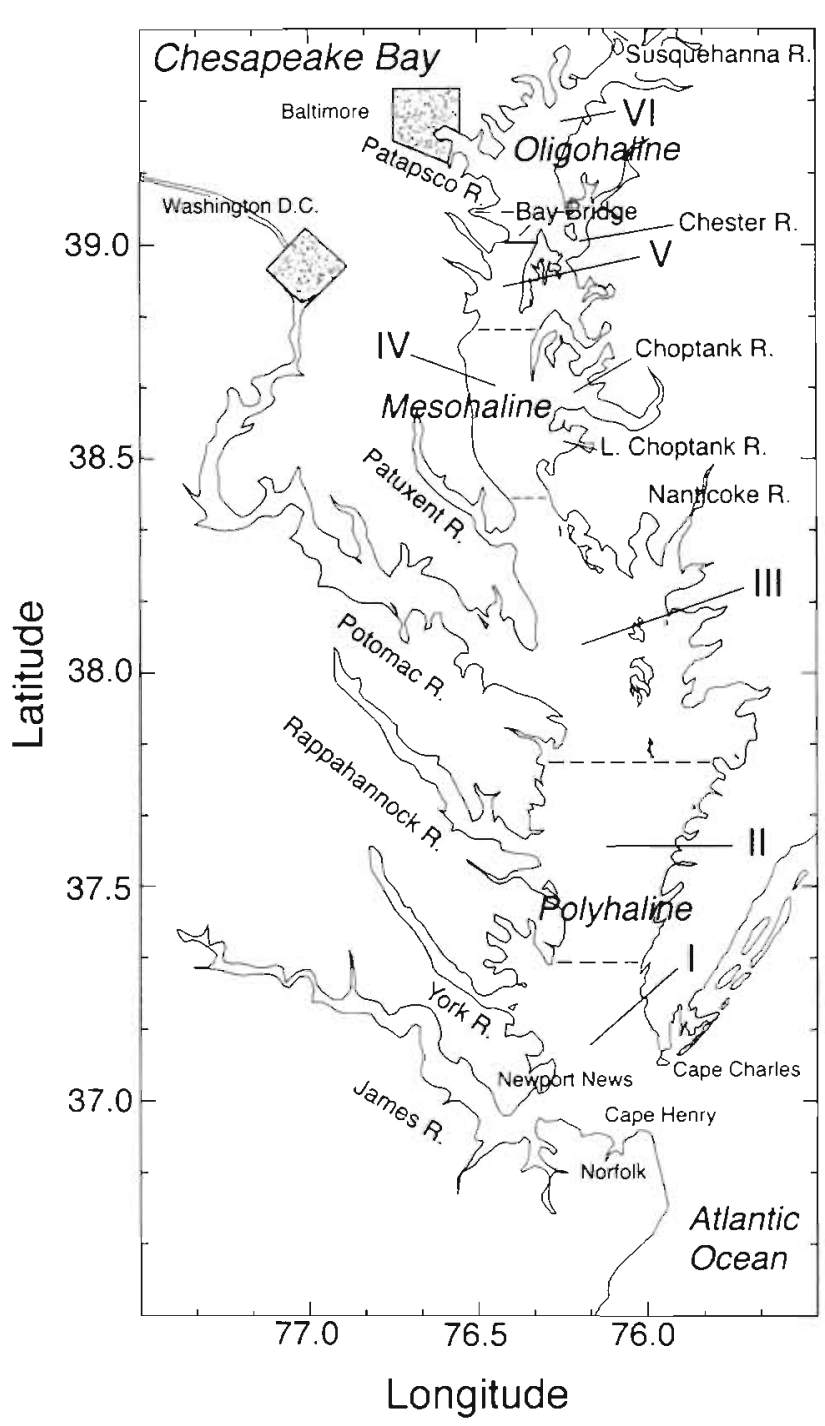

Fig. 1. Chesapeake Bay showing locations of the 6 regions chosen to represent major salinity provinces of the estuary, the principal rivers draining into the Bay, and major metropolitan areas. The salinity provinces are defined as: oligohaline ( $\mathrm{S}<10 \mathrm{psu})$, mesohaline (10 psu $<\mathrm{S}<20 \mathrm{psu})$, and polyhaline $(S>20$ psu). We used latitude as a proxy for the boundaries of the salinity provinces to define 6 regions: 1. 36.95 $-37.40^{\circ} \mathrm{N}$ (Mouth of Bay to Mobjack Bay); II, $37.41^{\circ}-$ $37.80^{\circ} \mathrm{N}$ (Mobjack Bay to Rappahannock R.); III, $37.81^{\circ}$ $38.40^{\circ} \mathrm{N}$ (Rappahannock R. to Patuxent R.); IV, $38.41^{\circ}-38.80^{\circ} \mathrm{N}$ (Patuxent R. to South R./Annapolis); V, 38.81 $-39.10^{\circ} \mathrm{N}$ (South R./Annapolis to Bay Bridge/Magothy R.); VI, 39.11 $-39.66^{\circ} \mathrm{N}$ (Bay Bridge/Magothy R. to Susquehanna Flats)

vacuum pressure filtration on glass fiber filters with small $(0.3$ to $0.8 \mu \mathrm{m})$ nominal pore sizes. The extracts were analyzed using spectrophotometry (Beckman DK-2 or equivalent, trichromatic equations; see Strickland \& Parsons 1968), or fluorometry (Turner model 110 or 111, or Turner Designs model 10) calibrated with spectrophotometric determinations. For samples col- 
lected prior to 1964, the unpublished method of Sargent (Scripps Institution of Oceanography, CA, USA) was used, consisting of filtration of $1 \mathrm{l}$ of sample through a Whatman No. 5 filter, extraction in $80 \%$ acetone, and measurements of absorbance at 550,667 and $750 \mathrm{~nm}$. Filtration of such a large volume of Bay water clogs the filters quickly, effectively lessening the pore size and allowing the retention of even small $(<1 \mu \mathrm{m})$ phytoplankton cells. Fluorometric measurements of chlorophyll $a$ in the 1960 s were performed on sample collected on $0.2 \mu \mathrm{m}$ membrane filters, methanol extraction of pigments, and measurement of fluorescence on a Turner model 110 or 111 fluorometer calibrated with a standard dilution series of chlorophyll a standards whose concentrations were determined spectrophotometrically. After 1969, the trichromatic method for multiple pigment determination was used (Strickland $\&$ Parsons 1968). Most of the data from the 1950s to the 1970 s were uncorrected for phaeopigments. Based on historical and recent data with both uncorrected and corrected values, the difference in methods produces a small error $(<5 \%$ overestimate) of chlorophyll for that period. Data from the CBP monitoring program used to develop regional models of mean, monthly chlorophyll $a$ were active chlorophyll a corrected for phaeopigments, and are determined by methods consistent with those used in the historical data. These cruise samples are taken on glass fiber filters (GFF or equivalent). $90 \%$ acetone extraction, and spectrophotometric determination of chlorophylls with trichromatic equations.

Data from each annual set of chlorophyll $a$, salinity (S), and temperature ( $\mathrm{T}$ ) observations were grouped by month and region, and mean, monthly (arithmetic mean) $\log _{10}$ chlorophyll a was computed for each of 6 regions selected to represent the major salinity provinces of the Bay. A set of autoregressive moving average (ARMA) (Shumway 1988) models with structural components reflecting the contributions of freshwater input, $\mathrm{S}$, and $\mathrm{T}$ was developed to predict the mean, monthly chlorophyll a concentration by region. The models were calibrated using data collected on the monitoring cruises spanning $>8$ yr (July 1984 to December 1992). The principal variables in the models were time of year, geographic location, freshwater flow, $S$, and T ARMA models have been used before to treat serially correlated data, i.e. measurements that are correlated with preceding measurements (cf. Jordan et al. 1991). In this type of analysis, the residuals express the degree to which a measurement departs from the previous pattern of measurements. We used a backwards elimination strategy for variables that appeared non-significant, i.e. if the residuals did not pass a 'white noise' test upon elimination of an apparently non-significant variable, that variable was retained in the analysis. The 'white noise' test is that provided by the ARIMA procedure of the ETS component of the SAS Software System (Sas Institute 1993), and is further documented in Ljung \& Box (1978). Three lags were used in the initial model and seasonality is modeled by the structural part of the model.

A complete record of the physical variables was needed to undertake the time-series modeling of historical chlorophyll $a$, and accordingly some properties had to be estimated to fill gaps in the data. We used historical T data from D. Cargo (unpubl.) taken from the pier of the Chesapeake Biological Laboratory on the Patuxent River (Solomons, Maryland) to fill minor gaps in the $\mathrm{T}$ record. We also used an ordinary least squares model (autocorrelation was not significant) to predict water $\mathrm{T}$ as a sine function of month. Gaps in the $S$ record were filled by prediction using an autoregressive model (AR1) (Shumway 1988) derived from the large number of concurrent observations of flow and $S$ for the Bay.

Freshwater flow with up to 8 time lags (months) was examined initially in the ARMA modeling, and once selected, the flow variables were forced into the models for the remainder of the selection process. To model seasonal effects, $\mathrm{S}$ and $\mathrm{T}$ with up to 4 time lags of each were examined. Linear time trends were also considered in this phase. Actual observations of physical variables for specific periods were then used as inputs to the ARMA models to predict chlorophyll $a$. We compared the concentrations of chlorophyll a predicted by the models to concentrations observed historically for the complete set of observations available back to 1950, and focusing on 4 specific periods between 1950 and $1980(1950-51,1965-66,1975-76,1978-79)$ that had the most complete sampling in time and space. We limited the periods for which predictions were made to those in each decade that had the greatest density of data to minimize the effects of sparse sampling in the historical record. In estimating the chlorophyll a value for each period, if the preceding period had data, differences between observed and predicted values were used in the ARMA part of the model. If data from the preceding period(s) were missing, the estimate was based on the structural part of the model only. Differences between observed and predicted chlorophyll a were used to support our inference of an effect on chlorophyll a concentrations unexplained by variability of freshwater flow and related physical properties, suggesting the difference had an underlying anthropogenic cause, such as historical changes in nutrient availability. We will refer later to 'flow detrended chlorophyll $a^{\prime}$ estimated by these procedures, reflecting the view that freshwater flow and its covariates are likely the most important factors controlling chlorophyll a concentrations in the Bay, which is commonly the case in river-dominated estuarine systems. 


\section{RESULTS}

\section{Freshwater flow}

Freshwater flow into Chesapeake Bay is dominated by the Susquehanna River at the northern extreme of the estuary. This single source supplies approximately $60 \%$ of the freshwater flowing into the Bay and up to $80 \%$ of the riverine input of dissolved inorganic $N$ (DIN). The annual cycle of flow from the Susquehanna River consists of a spring freshet that occurs between January and April, and whose timing and magnitude vary significantly from year to year (Fig. 2a). The average freshwater flow during the spring freshet for the period 1950 to 1994 was $-160 \times 10^{6} \mathrm{~m}^{3} \mathrm{~d}^{-1}$, with a range from $75 \times 10^{6}$ in 1969 to $>275 \times 10^{6} \mathrm{~m}^{3} \mathrm{~d}^{-1}$ in 1993 (Fig. 2b). Three prominent features characterize the flow data of the last 40 to $50 \mathrm{yr}$ : (1) a prolonged period of low flow in the 1960s; (2) a subsequent period of high flow in the 1970s; (3) a mix of flow conditions in the 1980s and 1990s, including a drought (1989) and recent years with extremely high flow $(1993,1994)$.

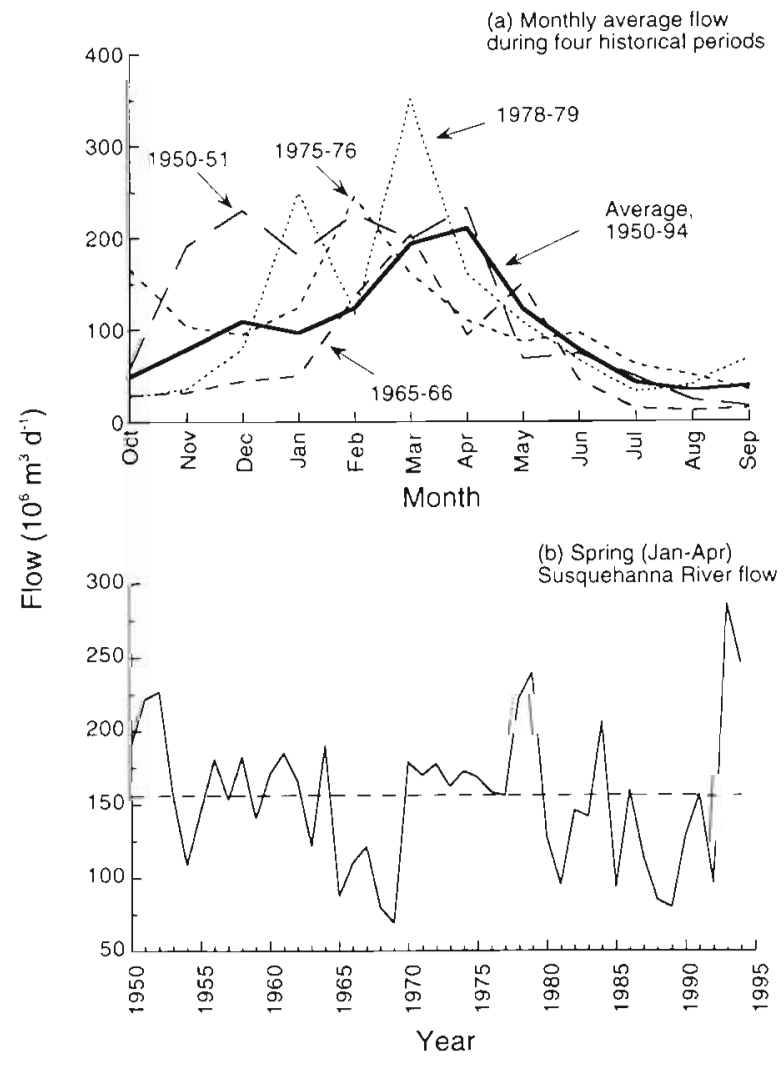

Fig. 2. Freshwater flow from the Susquehanna River as average, daily flow $\left(10^{6} \mathrm{~m}^{3} \mathrm{~d}^{-1}\right)$ for: (a) the water years (OctoberSeptember) 1950-51, 1965-66, 1975-76, and 1978-79, compared to the long-term (1950 to 1994) average $e_{i}(b)$ the period of the winter-spring freshet (January-April) compared to the long-term average $\left(157 \times 10^{6} \mathrm{~m}^{3} \mathrm{~d}^{-1}\right)$
Because of the strong correlation of freshwater flow and nutrient input, the sequential occurrence of a 'dry' period in the 1960 s and a 'wet' period in the 1970 s must be taken into account to distinguish an increase of chlorophyll a that reflects eutrophication from an effect of changing meteorological conditions.

\section{Surface chlorophyll a}

Phytoplankton biomass expressed as the observed concentration of chlorophyll $a$ in the surface mixed layer has increased in all 6 regions of the Bay since the early 1950s, with the seaward, polyhaline regions exhibiting the largest changes (Fig. 3, Table 1). The
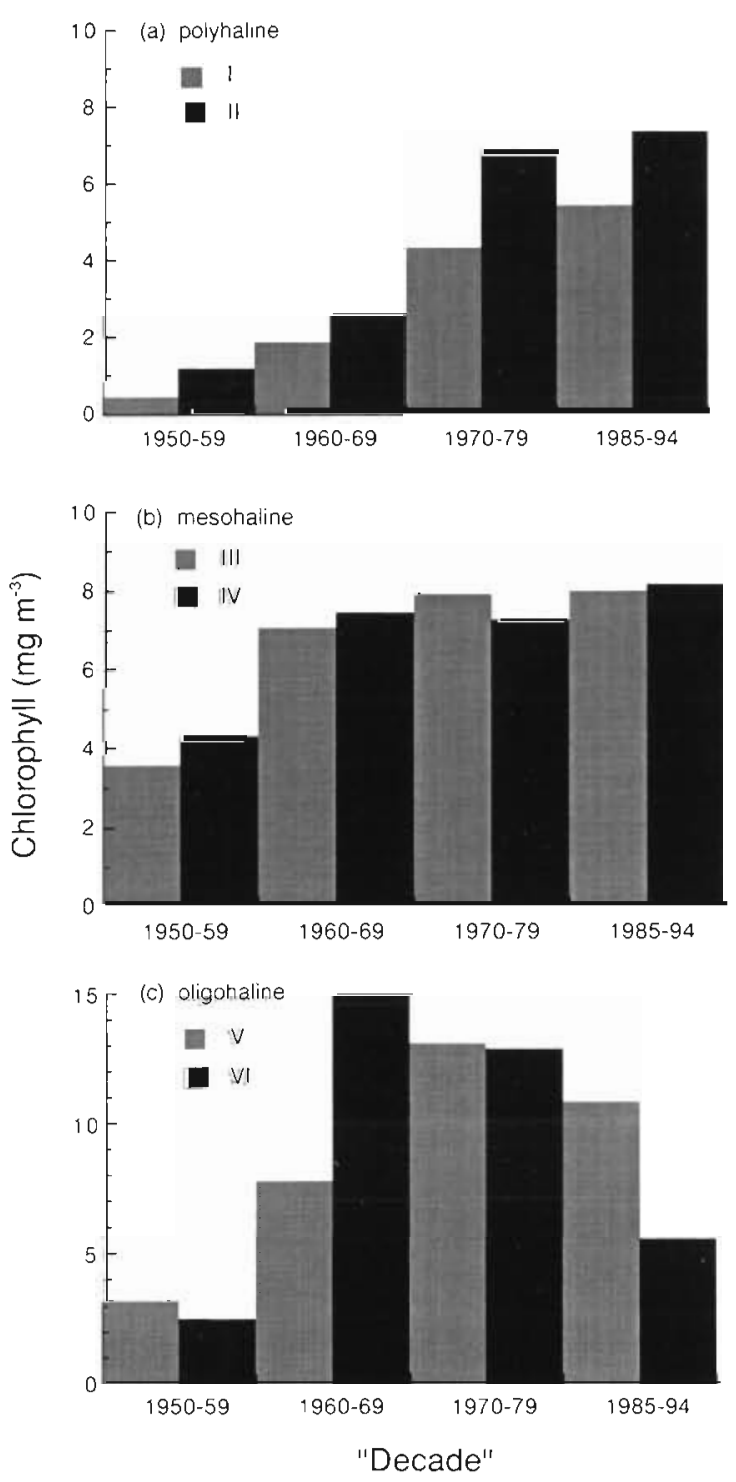

Fig. 3. Regional concentrations of surface chlorophyll $\left(\mathrm{mg} \mathrm{m}^{-3}\right)$ for 1950-59,1960-69,1970-79 and 1985-94: (a) regions I, il; (b) regions III, IV; (c) regions $V$, VI 
Table 1. Regional means of surface chlorophyll for 1950-59, $1960-69,1970-79$ and $1985-94$. Least squares means, uncorrected for flow. \% Diff.. percent difference of annual mean [chll for a specified region and period from corresponding [chl] in 1950-59

\begin{tabular}{|lrrrrr|}
\hline Period & Region & $\log _{10}[$ chl] & [chl] & \% Diff. & \multicolumn{1}{c}{ n } \\
\hline $1950-59$ & I & -0.34 & 0.46 & - & 41 \\
& II & 0.08 & 1.21 & - & 18 \\
& III & 0.55 & 3.58 & - & 108 \\
& IV & 0.64 & 4.33 & - & 7 \\
& V & 0.50 & 3.19 & - & 15 \\
& VI & 0.40 & 2.51 & - & 18 \\
$1960-69$ & I & 0.28 & 1.89 & 310 & 8 \\
& II & 0.42 & 2.61 & 115 & 9 \\
& III & 0.85 & 7.09 & 98 & 28 \\
& IV & 0.87 & 7.48 & 73 & 58 \\
& V & 0.89 & 7.79 & 144 & 97 \\
& VI & 1.19 & 15.59 & 521 & 295 \\
$1970-79$ & I & 0.64 & 4.39 & 853 & 101 \\
& II & 0.84 & 6.89 & 468 & 31 \\
& III & 0.90 & 7.95 & 122 & 100 \\
& IV & 0.86 & 7.29 & 68 & 206 \\
& V & 1.12 & 13.12 & 311 & 324 \\
& VI & 1.11 & 12.90 & 414 & 845 \\
$1985-94$ & I & 0.74 & 5.49 & 1093 & 1862 \\
& II & 0.87 & 7.40 & 510 & 2350 \\
& III & 0.90 & 8.03 & 124 & 1261 \\
& IV & 0.91 & 8.20 & 89 & 1022 \\
& V & 1.04 & 10.86 & 240 & 1164 \\
& VI & 0.75 & 5.57 & 122 & 1005 \\
& & & & & \\
\hline
\end{tabular}

mean chlorophyll a concentrations have increased 5 to 10 -fold in the polyhaline Bay (regions I, II), and about 1.5 - to 2 -fold in the oligohaline and mesohaline regions. Concentrations peaked by the 1960s in the oligohaline and mesohaline regions of the Bay (regions III-VI), but have continued to increase in the polyhaline Bay (regions I, II).

The distribution of data for the period of record, 1950 to 1994 , clearly illustrates the problem we faced in resolving a long-term trend of chlorophyll a from variability on shorter time scales (Fig. 4). The number of observations in the decade of the 1950s was low ( $\mathrm{n}=$ 207), and the Bay as a whole was not well represented, although 1950-51 was relatively well covered. There was a significant improvement of coverage in the 1960 s ( $\mathrm{n}=495$ ), particularly in the oligohaline and mesohaline Bay, and 1965-66 was sampled extensively. Data for the 1970 s were abundant $(\mathrm{n}=1601)$ and 2 periods, $1975-76$ and 1978-79 were quite well sampled. Chlorophyll $a$ observations in the most recent period, 1985-94, largely come from the CBP monitoring cruises, giving excellent coverage in both time and space and a large data set ( $\mathrm{n}>10000$ ) of coincident physical and biological measurements. Data were sufficient to create time-space composites of surface chlorophyll a for the 1960s, 1970s, and $1985-94$ by gridding and contouring the available chlorophyll a observations. These decadal composites (a) $1950 \mathrm{~s}$

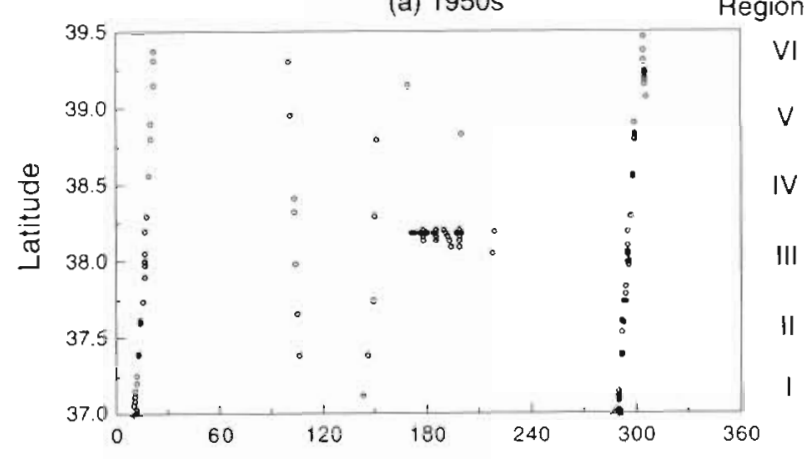

(b) $1960 \mathrm{~s}$

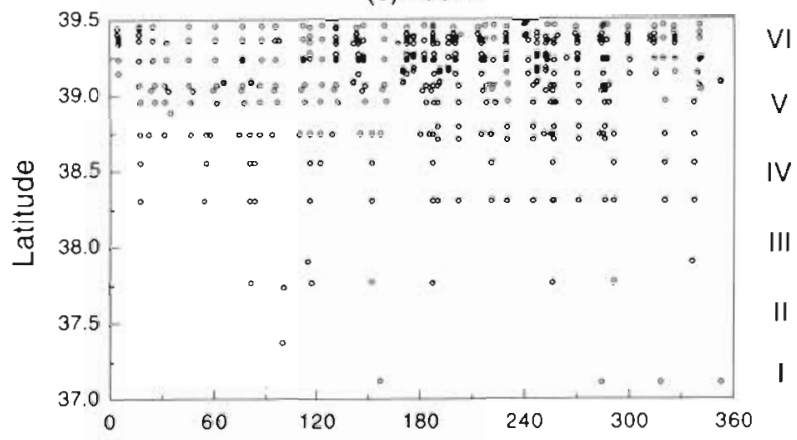

(c) $1970 \mathrm{~s}$

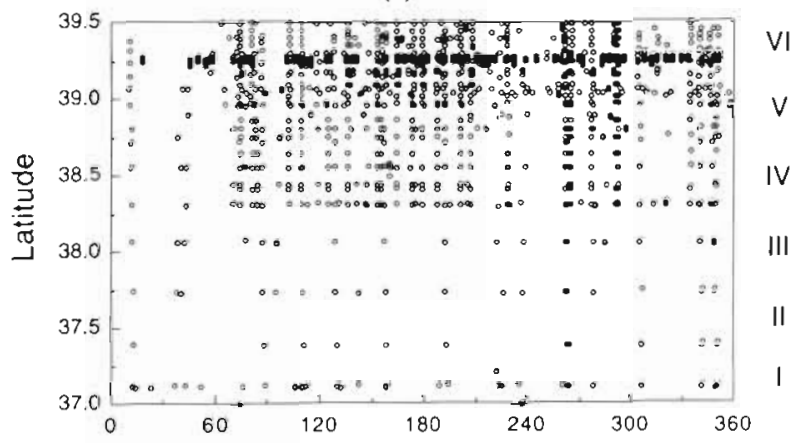

(d) $1985-94$

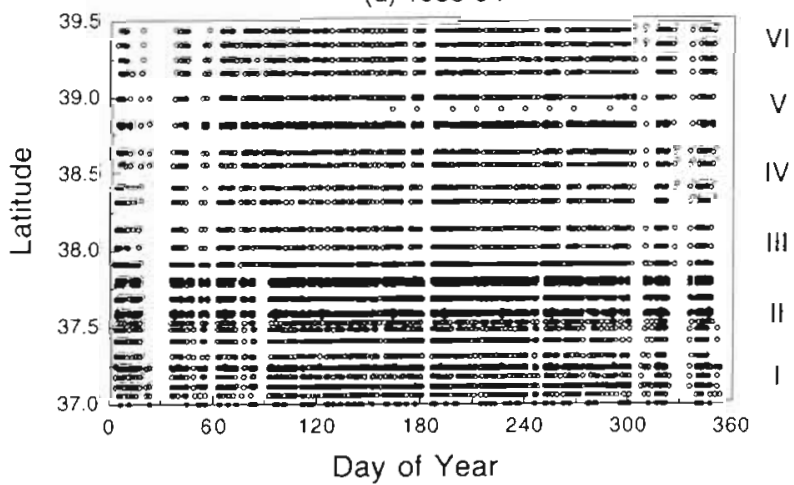

Fig. 4. Distribution of chlorophyll a observations for Chesapeake Bay, 1950 to 1994, showing: (a) sparse coverage in the 1950 s $(n=207)$; $(b)$ improved coverage in the 1960s $(n=495)$ and (c) $1970 \mathrm{~s}(\mathrm{n}=1601)$, and (d) excellent coverage in both time and space for 1985-94 $(n=10655)$, encompassing the period of observation used to develop the ARMA models 
show highest chlorophyll a (>30 $\mathrm{mg}$ $\mathrm{m}^{-3}$ ) in oligohaline regions of the Bay during summer in 1960-69 (Fig. 5a), and the absence of a spring chlorophyll a maximum of diatoms in the mesohaline to polyhaline Bay (Malone 1992, Harding 1994, Glibert et al. 1995). In 1970-79, high surface chlorophyll a accompanied pronounced spring phytoplankton blooms that covered a large part of the estuary during April and May, and high concentrations also occurred in July and August in the oligohaline and mesohaline Bay (Fig 5b). In 1985 to 1994 , the chlorophyll a distribution was generally similar to that of the 1970s, with highest concentrations in the mesohaline to polyhaline during spring, and in the oligohaline to mesohaline during summer (Fig. 5c). A mix of years with low and high freshwater flow has occurred since 1985, distinct from the period of consistently high flow during the 1970s; this difference may explain the lower chlorophyll a concentrations apparent in the recent composite. There were too few data and the distribution of the available observations in time and space was insufficient for the 1950 s to create a time-space composite of surface chlorophylla.

\section{Regional ARMA models}

The variables, regression coefficients, and $t$-values for regional chlorophyll a models for the Bay are given in Table 2. Freshwater flow, $S, T$, and time of year were the most important predictors of mean monthly chlorophyll $a$ in the 6 regions. Time-series of chlorophyll a concentrations derived from the models for 1950-94 are presented in Fig. 6, with the observed chlorophyll a concentrations superimposed on the model predictions. The corresponding normalized residuals presented in Fig. 7 express the differences of observed chlorophyll a from model predictions, showing a preponderance of negative residuals in the mesohaline and polyhaline regions of the Bay during the 1950s, 1960s, and 1970s. Observed chlorophyll a concentrations for the historical periods (prior to 1984) that were significantly lower (or higher) than predicted indicate that the model(s) based on modern

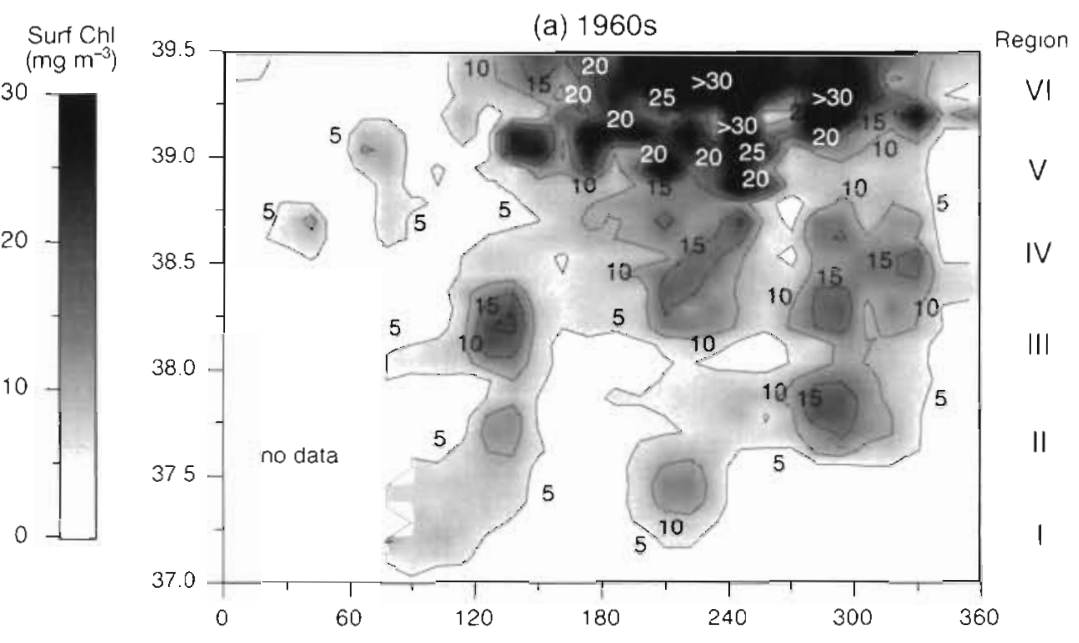

(b) $1970 \mathrm{~s}$

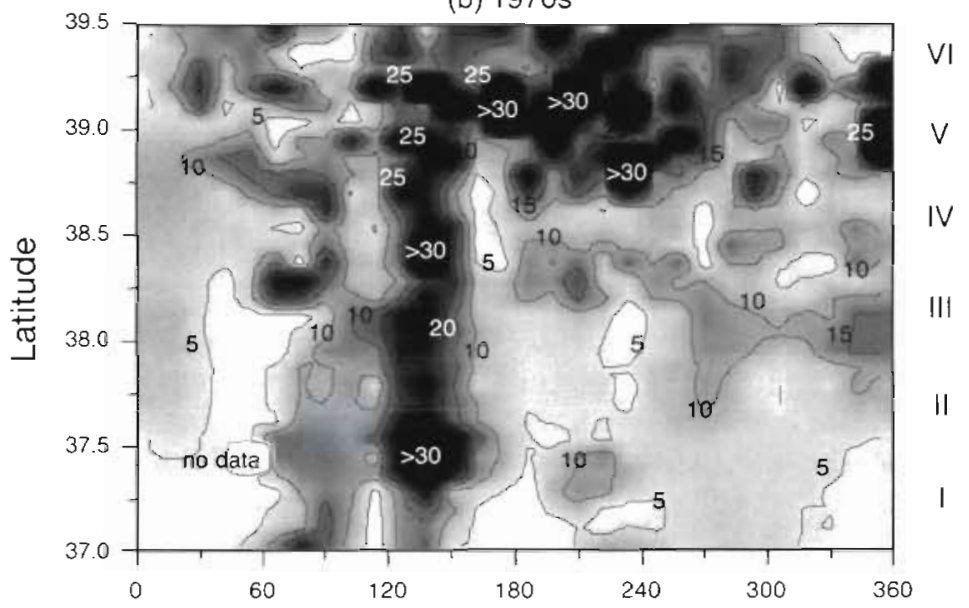

(c) $1985-94$

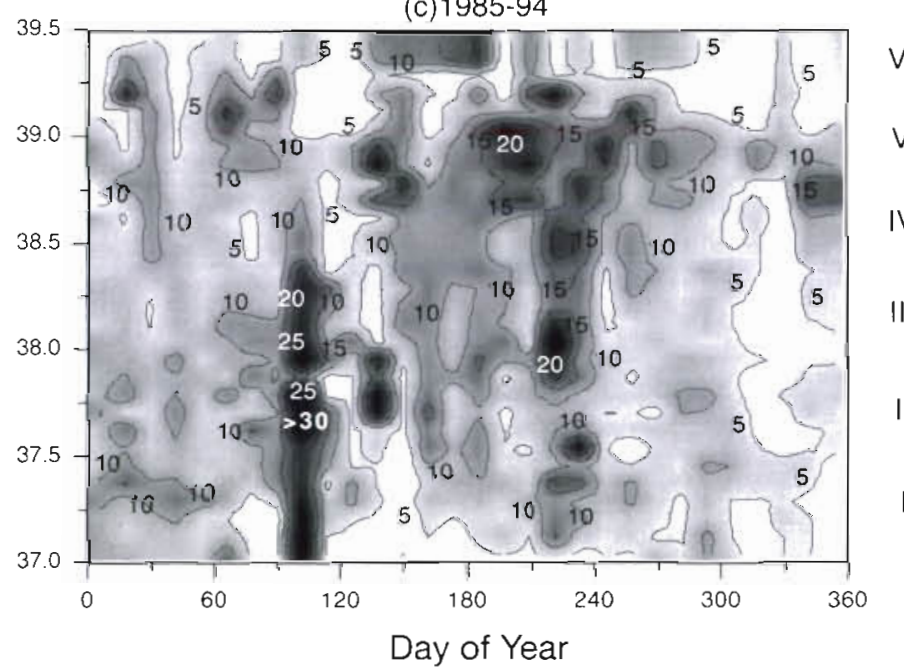

Fig 5. Time-space composites of surface chlorophyll ( $\mathrm{mg} \mathrm{m}^{-3}$ ) for: (a) 1960s; (b) 1970s; (c) 1985-94, showing differences in locations of peak chlorophyll for data grouped by decade. For reference, the polyhaline region of the Bay is defined by latitudes $<37.80^{\circ} \mathrm{N}$, the mesohaline, $37.81^{\circ}-38.80^{\circ} \mathrm{N}$, and the oligohaline, $>38.80^{\circ} \mathrm{N}$ 
Table 2. Variables selected as important predictors of average, monthly $\log _{10}$ [chl] for each of 6 regions in Chesapeake Bay using autoregressive moving average. (ARMA) models. Nomenclature for the variables flow, salinity (salin), and temperature (temp) is 'variable (lag, in months)'. Tabulated values are the regression coefficient ( $t$-value); $r^{2}$ values are given in the last row

\begin{tabular}{|c|c|c|c|c|c|c|}
\hline \multirow[t]{2}{*}{ Variable } & \multicolumn{6}{|c|}{ Region } \\
\hline & I & II & III & IV & V & $\mathrm{VI}$ \\
\hline Intercept & $1.29(4.01)$ & $1.48(5.49)$ & $1.49(6.98)$ & $1.11(5.48)$ & $1.10(5.26)$ & $1.30(6.38)$ \\
\hline Autoregression & $0.290(2.86)$ & $0.406(4.24)$ & $0.398(4.20)$ & $0.191(1.82)$ & $0.0388(0.36)$ & $0.198(1.80)$ \\
\hline $\begin{array}{l}\text { Flow } \\
\text { Flow (1) } \\
\text { Flow (2) } \\
\text { Flow (3) } \\
\text { Flow (4) }\end{array}$ & $0.000837(2.28)$ & $0.000529(1.54)$ & $0.000511(1.59)$ & $\begin{array}{l}0.000642(1.79) \\
0.000689(2.58)\end{array}$ & $-0.000524(-1.06)$ & $-0.00161(-3.06)$ \\
\hline $\begin{array}{l}\text { Salin } \\
\text { Salin (1) } \\
\text { Salin (2) } \\
\text { Salin (3) } \\
\text { Salin (4) }\end{array}$ & $-0.0304(-2.48)$ & $-0.0415(-2.90)$ & $-0.0431(-3.44)$ & $-0.0285(-2.52)$ & $\begin{array}{c}-0.0323(-2.30) \\
0.0146(1.48)\end{array}$ & $\begin{array}{c}0.0331(2.07) \\
-0.0340(-2.63)\end{array}$ \\
\hline $\begin{array}{l}\text { Temp } \\
\text { Temp (1) } \\
\text { Temp (2) } \\
\text { Temp (3) } \\
\text { Temp (4) }\end{array}$ & $0.00780(2.14)$ & $0.00573(1.58)$ & & $0.00568(2.01)$ & $0.0148(4.96)$ & $\begin{array}{c}0.0159(1.33) \\
-0.0217(-2.02)\end{array}$ \\
\hline Time & & & & $-0.00157(-2.17)$ & $-0.0014(-1.83)$ & $-0.00307(-2.90)$ \\
\hline$r^{2}$ & 0.30 & 0.38 & 0.44 & 0.38 & 0.36 & 0.49 \\
\hline
\end{tabular}

(1984-92) conditions produced biased estimates of historical values, thus causing a rejection of the null hypothesis that chlorophyll a was unchanged from that period to the present. Differences between observed and predicted chlorophyll $a$ for the 1950s, 1960s and 1970 s do not, therefore, represent a failure of the models, but rather differences in the relationships between chlorophyll $a$ and physical variables in the historical periods from those of the modern Bay.

The time series of observed and predicted chlorophyll a and the normalized residuals show: (1) observed and predicted chlorophyll a concentrations matched reasonably well for the years that were used to develop the models (1984-92), with some exceptions when the models failed to capture extremely high concentrations of chlorophyll a associated with blooms of unusual magnitude; (2) chlorophyll a concentrations in the $1950 \mathrm{~s}, 1960 \mathrm{~s}$, and 1970 s were predominantly lower than predicted by the models, particularly in the mesohaline to polyhaline Bay (regions I-IV) that are most susceptible to nutrient limitation; (3) observed and predicted chlorophyll a concentrations were lower in the 1960 s than in the 1970 s, probably resulting from low flow and nutrient loading in the 'dry' 1960 s as compared to the 'wet' 1970 s; (4) interannual variability was high for both observed and predicted chlorophyll a concentrations in the $1970 \mathrm{~s}$, and this variability was most strongly expressed in the mesohaline to polyhaline Bay, reflecting the spatial and temporal heterogeneity of phytoplankton that prevailed in that period.
An analysis of the flow-detrended chlorophyll a data revealed that historical period, region, and season each explained significant proportions of the variance in chlorophyll $a(p<0.05)$. The interactions of historical period with region $(p=0.07)$, and of historical period with season $(p=0.01)$ were also significant (Table 3$)$. This specificity of increases in phytoplankton biomass to region and season was further supported by the differences between observed and predicted chlorophyll a concentrations in the ARMA models for the 4 well sampled historical periods (Table 4). These results indicate that most of the recent increase of phytoplankton biomass in Chesapeake Bay occurred between 1950-51 and 1978-79 in the mesohaline and polyhaline regions, and that since the mid-1980s, chlorophyll a concentrations have been highly variable from year to year but have not increased significantly.

The seasonal and spatial specificities of changes in phytoplankton biomass are exemplified by the following observations: (1) 1950-51-chlorophyll a concentrations were lower than predicted by the models for nearly all seasons and regions, with the largest differences occurring in the mesohaline and polyhaline regions (I-IV); (2) 1965-66-mixed results included observed chlorophyll a concentrations that were lower than predicted for the mesohaline regions (III, IV) in spring and summer, and for the oligohaline region (V) during winter and spring, and observed concentrations for the northermmost Bay (region VI) that were uniformly higher than predicted; (3) 1975-76-observed 

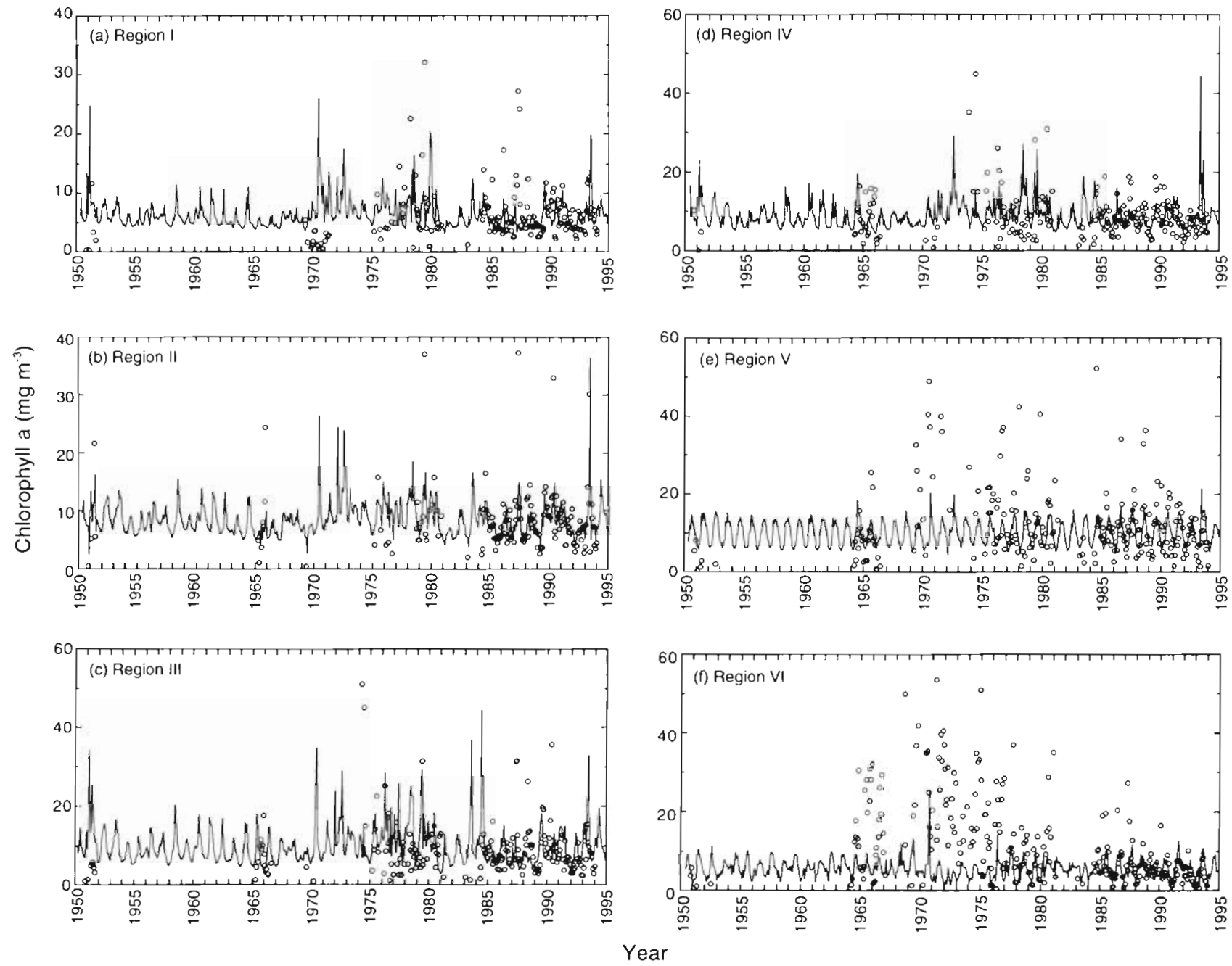

Fig. 6. Time-series of surface chlorophyll $\left(\mathrm{mg} \mathrm{m}^{-3}\right)$ for 6 regions of the Bay, spanning the period 1950 to 1994 . The line represents the output of ARMA models; $(0)$ actual observations of chlorophyll from the historical database and monitoring cruises archived at EPA's Chesapeake Bay Program

chlorophyll a concentrations in the mesohaline and polyhaline Bay (regions I-III) were generally lower than predicted, and in the oligohaline regions (V, VI) observed concentrations were higher than predicted; (4) 1978-79-observed chlorophyll a concentrations were lower than predicted for the mesohaline in spring, higher than predicted for the mesohaline and oligohaline regions (IV-VI) in winter, and only small differences were detected between observed and predicted chlorophyll a in other seasons and regions.

\section{DISCUSSION}

Regional means and time-space composites of chlorophyll a concentrations grouped by decade have suggested previously that phytoplankton biomass in Chesapeake Bay has increased in the years since
World War II (Figs. 3 \& 5; see also Harding 1994). Prior to this study, however, a statistically valid analysis to separate a long-term increase of phytoplankton biomass from seasonal and interannual variability had not been performed. Other studies suggesting that the high variability of phytoplankton biomass in the Bay is principally driven by differences in freshwater flow and an effect on nutrient loads (cf. Malone et al. 1988, Malone 1992, Harding 1994) led us to develop the ARMA models described here to correct for flow, making it possible to resolve an historical increase of chlorophyll a with statistical confidence. The use of these models identified a significant increase of phytoplankton biomass in Chesapeake Bay between the early 1950 s and the late 1970 s and specified those regions of the Bay that have shown significant responses to enrichment in recent decades. 

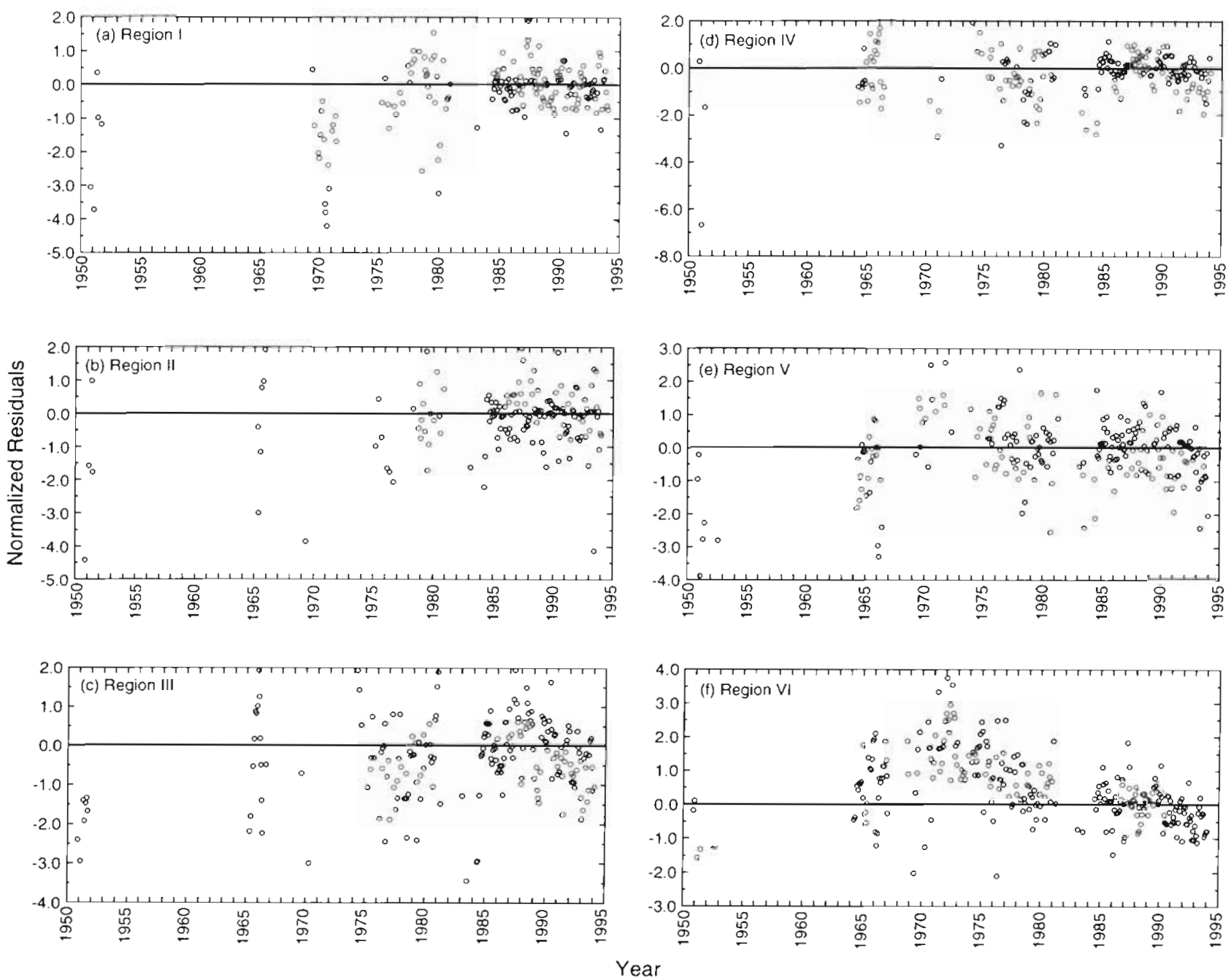

Fig. 7. Normalized residuals (= observed residuals divided by SD of residuals) for observed and predicted chlorophyll a by region for the period 1950 to 1994. The horizontal solid line is a normalized residual of zero; negative residuals correspond to observed chlorophyll a concentrations lower than predicted; positive residuals correspond to observed chlorophyll a concentrations higher than predicted

Table 3. Analysis of variance (ANOVA) of time and space trends in the chlorophyll a concentration $\left(\log _{10}[\mathrm{chl}]\right)$ in Chesapeake Bay for 4 historical periods

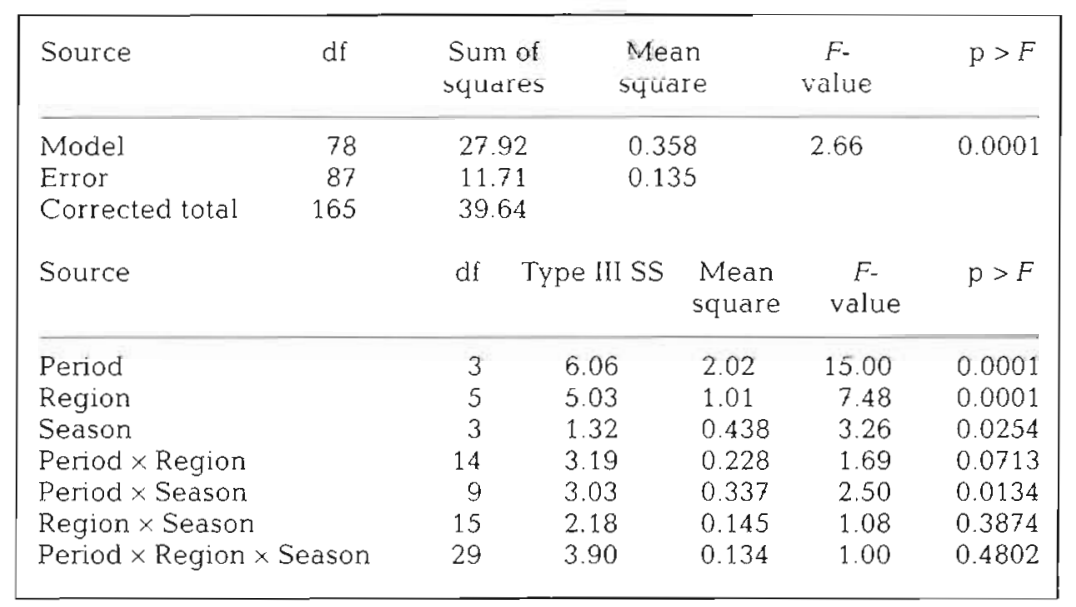

Based on the confirmation of increased phytoplankton biomass in the Bay during the past 40 to $50 \mathrm{yr}$, we suggest that an underlying cause is increased $N$ loading and a concomitant lessening of $N$ limitation in the seaward regions of the estuary. It is widely accepted that phytoplankton biomass is limited by $\mathrm{N}$ on a Bay-wide scale (Malone 1992, Malone et al. 1996), and that the mesohaline to polyhaline reach is particularly sensitive to increases of $N$ (e.g. D'Elia et al. 1983, 1986. Harding 1994). Earlier analyses of nutrient data emphasized the role of $\mathrm{N}$ in regulating phytoplankton biomass and productivity in the seaward, 
Table 4. Deviations of observed $\log _{10}$ [chl] from estimates of ARMA models. Negative values indicate that the historical chlorophyll value was below the value predicted for similar hydrologic conditions in the modern Bay (post-1985) and positive values indicate the historical value was higher than predicted

\begin{tabular}{|c|c|c|c|c|c|c|c|}
\hline \multirow{2}{*}{$\begin{array}{l}\text { Historical } \\
\text { period }\end{array}$} & \multirow[t]{2}{*}{ Season } & \multicolumn{6}{|c|}{ Reguon } \\
\hline & & l & Il & III & IV & V & VI \\
\hline \multirow[t]{4}{*}{$1950-51$} & Spring & -0.23 & -0.14 & $-0.42^{\circ}$ & -0.57 & $-0.65^{\circ}$ & -0.34 \\
\hline & Summer & -0.31 & nd & -0.36 & nd & nd & nd \\
\hline & Autumn & $-1.15^{\bullet}$ & $-1.15^{\circ}$ & $-0.74^{\circ}$ & 0.23 & -0.06 & 0.15 \\
\hline & Winter & $-1.52^{\circ}$ & -0.46 & $-0.99^{\circ}$ & $-2.08^{\circ}$ & $-1.09^{\circ}$ & -0.51 \\
\hline \multirow[t]{4}{*}{$1965-66$} & Spring & nd & nd & $-0.54^{\circ}$ & -0.19 & $-0.53^{\bullet}$ & 0.26 \\
\hline & Summer & nd & nd & -0.22 & nd & & $0.43^{\circ}$ \\
\hline & Autumn & nd & 0.59 & 0.45 & 0.39 & 0.06 & $0.90^{\circ}$ \\
\hline & Winter & nd & nd & 0.01 & 0.01 & $-0.53^{\circ}$ & 0.20 \\
\hline \multirow[t]{4}{*}{$1975-76$} & Spring & -0.40 & -0.36 & 0.09 & -0.15 & 0.19 & 0.26 \\
\hline & Summer & -0.06 & -0.59 & -0.11 & 0.13 & 0.30 & $0.72^{\circ}$ \\
\hline & Autumn & nd & nd & nd & nd & 0.19 & 0.45 \\
\hline & Winter & -0.30 & -0.35 & -0.64 & -0.19 & 0.15 & 0.32 \\
\hline \multirow[t]{4}{*}{$1978-79$} & Spring & 0.37 & 0.01 & -0.32 & -0.32 & 0.00 & 0.07 \\
\hline & Summer & 0.13 & -0.21 & -0.09 & 0.04 & 0.14 & 0.33 \\
\hline & Autumn & 0.11 & 0.06 & 0.04 & -0.19 & 0.06 & $0.55^{\circ}$ \\
\hline & Winter & -0.06 & -0.03 & 0.03 & 0.25 & 0.20 & 0.34 \\
\hline
\end{tabular}

polyhaline regions of the Bay, while demonstrating seasonal shifts in the nutrient(s) that limits phytoplankton abundance (Fisher et al. 1988, 1992, Conley \& Malone 1992, Harding et al. 1992a, 1994, Harding 1994). These studies documented transient roles of $\mathrm{P}$ and $\mathrm{Si}$ in regulating phytoplankton dynamics in the oligohaline and upper mesohaline regions of the Bay, but unanimously concluded that $N$ is the essential limiting macronutrient for phytoplankton in the lower mesohaline to polyhaline regions. DIN is depleted annually in the mainstem of the Bay from the Potomac River to the Bay's mouth following the winter-spring bloom of diatoms in April and May (cf. Harding et al. 1986, Fisher et al. 1988, 1992). This reach of the Bay is the largest by area and volume (Cronin \& Pritchard 1975), and changes in the $\mathrm{N}$ supply are readily manifested in chlorophyll a concentrations that are almost always lower than concentrations in the more northerly regions of the Bay (Harding et al. 1986, 1992a, 1994, Fisher et al. 1988, Malone 1992, Harding 1994).

Such a pattern of lessened $N$ limitation in the lower estuary would be consistent with the elevated DIN inputs that are suggested by increasing concentrations in the oligohaline and mesohaline regions which have been observed since the 1960s (see Harding 1994, Fig. 15 therein), and with the low, but increasing chlorophyll a concentrations in the polyhaline Bay (this paper, and Harding 1994). It is also consistent with nutrient budgets that report historical increases of total $N$ (TN) from 4.8- to 7.9-fold, and of total P (TP) from 13- to 24-fold since European settlement, with annual increases of TN and TP from 1913 to 1954 of 2 to $5 \% \mathrm{yr}^{-1}$ and $10 \% \mathrm{yr}^{1}$, respectively (Boynton et al. 1995). To estimate the effect of $\mathrm{N}$ increases of this magnitude on $\mathrm{N}$ loads, we computed nitrate $\left[\mathrm{NO}_{3}{ }^{-}\right]$inputs to the Bay for the recent several decades using actual flow rates, and: (1) constant headwater concentrations at the current level of $100 \mu \mathrm{M}$, or (2) assumptions of 1 or $2 \mu \mathrm{M} \mathrm{Yr}^{-1}$ increases for the period from 1950-80 from a baseline concentration of $50 \mu \mathrm{M}$, i.e. the mean $\left[\mathrm{NO}_{3}{ }^{-}\right]$for the early 1960 s and the value used by Malone et al. (1988) to compute $\mathrm{NO}_{3}{ }^{-}$loads to the mesohaline (Fig. 8). The effect on $\mathrm{N}$ loads in the 1950 s is dramatic, and while this loading diagram is highly conjectural because of the relatively sparse nutrient data for the 1950s and 1960s, we believe it is a reasonable depiction of the likely change in $\mathrm{N}$ loading to the Bay during that period.

Prolonged occurrences of low and high freshwater flow, such as occurred in the Chesapeake Bay region during the 1960 s and 1970 s, dominate non-point source nutrient loads and strongly influence phytoplankton biomass. We observed this effect in the overall distributions of chlorophyll a for these decades as the absence of a spring bloom in the polyhaline regions during the 1960 s, in contrast to bloom conditions during the 1970 s (Fig. 5a, b). It is obvious that a years-long period of low flow and reduced nutrient loads that resulted in low chlorophyll $a$, followed by a period of high flow and elevated nutrient loads that produced increases of chlorophyll $a$, superimposed on the presumed period of overenrichment, complicates the detection of trends. But events of shorter duration can also have a pervasive effect on phytoplankton dynamics and hence mask signals that connote change. For example, a drought from fall 1988 through mid-spring 1989 in the Chesapeake Bay watershed led to exceedingly low flow during the time when the freshet usually occurs. The result was an absence of a spring bloom that year, providing in a sense a 'natural experiment' wherein low flow produced low nutrient input, with $\mathrm{NO}_{3}{ }^{-}$loads comparable in magnitude to values projected for the early 1950 s (Fig. 8b). This condition yielded greatly reduced chlorophyll a concentrations throughout the Bay (Harding et al. 1992a, 1994), although not as low as those in the 1950 s (this paper, and Harding 1994). 


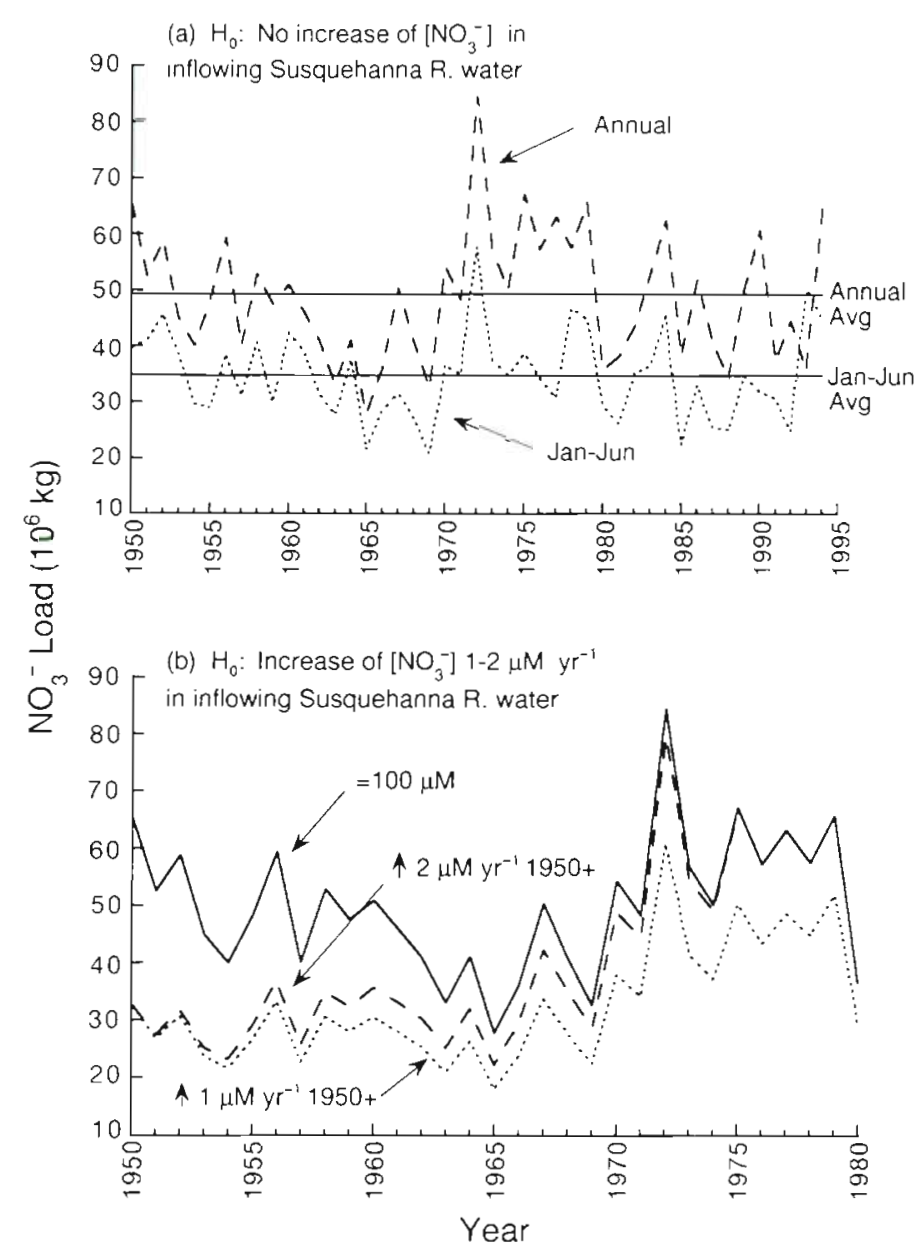

Fig. 8. Estimates of nitrate $\left(\mathrm{NO}_{3}^{-}\right)$loads to the Bay from the Susquehanna River $\left(10^{6} \mathrm{~kg}\right)$, using actual flow rates and estimates of headwater concentrations. The values in (a) for winter-spring (January-June) and annual loadings for 1950 to 1994 are based on the assumption of a constant $\left[\mathrm{NO}_{3}^{-}\right]$in the inflowing freshwater at the current concentration $(100 \mu \mathrm{M})$; values in (b) are based on a starting (1950) concentration of $50 \mu \mathrm{M}$ and the indicated rates of increase of 1 or $2 \mu \mathrm{M} \mathrm{yr}^{-1}$, to a maximum value of $100 \mu \mathrm{M}$

Examples of the last several years are also instructive, albeit frustrating from the standpoint of detecting change. Uncommon flow conditions have occurred in the Chesapeake Bay during the early to mid-1990s, with several years of nearly unprecedented freshwater input from the Susquehanna River that have carried sizable loads of $N$ and $P$ into the system, swamping efforts to reduce inputs from the watershed. The present conditions are reminiscent of the 1970 s when high concentrations of chlorophyll a occurred throughout the estuary during the prolonged 'wet' period of above-average flow. In 1993 and 1994, the total volume of freshwater input to the Bay was more than double the volume generated during June 1972 from Tropical Storm Agnes (Agnes $=79.8 \times 10^{9} \mathrm{~m}^{3} ; 1993=$
$165 \times 10^{9} \mathrm{~m}^{3} ; 1994=177 \times 10^{9} \mathrm{~m}^{3}$ ), although the recent freshets have been earlier and occurred over a period of 1 to 2 mo rather than over a few days as in Agnes. During winter 1996, we again witnessed extremely high freshwater flow following a major East coast blizzard and the subsequent melt of ice and snow in the Bay's watershed. Peak flow from the Susquehanna River was $2225 \times 10^{6} \mathrm{~m}^{3} \mathrm{~d}^{-1}$, as compared to 2462 $\times 10^{6} \mathrm{~m}^{3} \mathrm{~d}^{-1}$ during Agnes. This condition persisted into the summer of 1996 and chlorophyll $a$ concentrations were unprecedented in the modern Bay (Harding et al. unpubl.).

These years of anomalous low or high flow complicate the separation of changes in phytoplankton biomass that might reflect improvement of water quality from the predominant influence of meteorological conditions on freshwater flow and nutrient loads. The seasonal and interannual variability of chlorophyll a that is imparted, in large measure, by the underlying patterns of freshwater flow must be considered if we are to detect trends that truly represent environmental change. Cloern (1996) eloquently described this problem from the perspective of analyzing for changes in phytoplankton blooms on a global scale, using years of study on the San Francisco Bay as a case history for an estuary. The historical findings we present in this paper for the Chesapeake Bay lend further support to this point of view and indicate the need for a careful removal of variability in quantifying trends.

To this point, the simple, predictive models presented here enabled us to resolve the signal of interest-a long-term increase of phytoplankton biomass as a measure of probable nutrient overenrichment-from the 'static' or noise of fluctuations driven by seasonal and interannual variability of freshwater flow. We believe a similar approach can be used to gauge improvements of water quality in response to future nutrient reductions. This approach entails comparing chlorophyll a concentrations measured on monitoring cruises to predictions from models to remove the effects of flow and determine if chlorophyll a begins a downward turn in 1996 and beyond. Data are also available from aircraft remote sensing of ocean color in the Bay that give higher spatial and temporal resolution of chlorophyll $a$ and improved detection of blooms (Harding et al. 1992a, 1994). These data are currently being combined with shipboard observations and regional chlorophyll a models to analyze for changes in phytoplankton biomass in the Bay in response to remediation efforts. 
Acknowledgements. We thank K. Arrigo, L. Bahner, W Boynton, C. D'Elia, E. Itsweire, M. Leffler, T Malone, and several anonymous reviewers for helpful comments on the manuscript during its preparation, and acknowledge the support of University of Maryland Sea Grant College, NOAA Chesapeake Bay Office, NASA Ocean Biogeochemistry Program, and the NSF Land-Margin Ecosystem Research (LMER PROTEUS, TIES) Program for this research. Contribution No. 2997 of the Horn Point Laboratory, University of Maryland Center for Environmental Science, University System of Maryland.

\section{LITERATURE CITED}

Boicourt WC (1992) Influences of circulation processes on dissolved oxygen in Chesapeake Bay. In: Smith $D$, Leffler $M$ Mackiernan G (eds) Oxygen dynamics in Chesapeake Bay: a synthesis of recent research. University of Maryland Sea Grant College Publ, College Park, MD, p 7-59

Boynton WR, Garber JH, Summers R, Kemp WM (1995) Inputs, transformations, and transport of nitrogen and phosphorus in Chesapeake Bay and selected tributaries. Estuaries 18:285--314

Boynton WR, Kemp WM, Keefe CW (1982) A comparative analysis of nutrients and other factors influencing estuarine phytoplankton production. In: Kennedy VS (ed) Estuarine comparisons. Academic Press, New York, p 69-90

Carpenter JH, Pritchard DW, Whaley RC (1969) Observations of eutrophication and nutrient cycles in some coastal plain estuaries. In: Eutrophication: causes, consequences, correctives - proceedings of a symposium. US Nat Acad Sci Publ 1700, Washington, DC, p 210-221

Cloern JE (1996) Phytoplankton bloom dynamics in coastal ecosystems: a review with some general lessons from sustained investigation of San Francisco Bay, California. Rev Geophys 34:127-168

Cloern JE, Alpine AE, Cole BE, Wong RLJ, Arthur JF, Ball MD (1983) River discharge controls phytoplankton dynamics in the northern San Francisco Bay estuary. Estuar Coast Shelf Sci 16:415-429

Cole B, Cloern JE (1984) Significance of biomass and light availability to phytoplankton productivity in San Francisco Bay. Mar Ecol Prog Ser 17:15-24

Conley DJ, Malone TC (1992) The annual cycle of dissolved silicate in Chesapeake Bay: implications for the production and fate of phytoplankton biomass. Mar Ecol Prog Ser $81: 121-128$

Cooper WR, Brush GS (1991) Long-term history of Chesapeake Bay anoxia. Science 254:992-996

Cronin WB, Pritchard DW (1975) Additional statistics on the dimensions of Chesapeake Bay and its tributaries: crosssection widths and segment volumes per meter depth. Spec Rep. 42, Ref No. 75-3, Chesapeake Bay Inst, Johns Hopkins Univ, Baltimore, MD

D'Elia CF (1987) Nutrient enrichment of the Chesapeake Bay. Environment (Wash DC) 29:6-33

D'Elia CF, Nelson DM, Boynton WR (1983) Chesapeake Bay nutrient and plankton dynamics: III. The annual cycle of dissolved silicon. Geochim Cosmochim Acta 47:1945-1955

D'Elia CF, Sanders JG, Boynton WR (1986) Nutrient enrichment studies in a coastal plain estuary: phytoplankton growth in large-scale, continuous cultures. Can J Fish Aquat Sci 43:397-406

Fisher TR, Harding LW Jr, Stanley DW, Ward LG (1988) Phytoplankton, nutrients and turbidity in the Chesapeake, Delaware and Hudson estuaries. Estuar Coast Shelf Sci $27: 61-93$
Fisher TR, Peele ER, Ammerman JW, Harding LW Jr (1992) Nutrient limitation of phytoplankton in Chesapeake Bay. Mar Ecol Prog Ser 82:51-63

Gilmartin M, Degobbis D, Revelante N, Smodlaka N (1990) The mechanism controlling plant nutrient concentrations in the northern Adriatic Sea. Int Rev Gesamten Hydrobiol 75:425-445

Glibert PM, Conley DJ, Fisher TR, Harding LW Jr, Malone TC (1995) The spring bloom of 1990 in Chesapeake Bay. Mar Ecol Prog Ser 122:27-43

Harding LW Jr (1994) Long-term trends in the distribution of phytoplankton in Chesapeake Bay: roles of light, nutrients and streamflow. Mar Ecol Prog Ser 104:267-291

Harding LW Jr, Itsweire EC, Esaias WE (1992a) Determination of phytoplankton chlorophyll concentrations in the Chesapeake Bay with aircraft remote sensing. Remote Sens Environ 40:79-100

Harding LW Jr, Itsweire EC, Esaias WE (1994) Estimates of phytoplankton biomass in the Chesapeake Bay from aircraft remote sensing of chlorophyll concentrations, 1989-92. Remote Sens Environ 49:41-56

Harding LW Jr, Leffler M, Mackiernan GB (1992b) Dissolved oxygen in the Chesapeake Bay: a scientific consensus. Maryland Sea Grant College, Publication No. UM-SG-TS92-03, College Park, MD

Harding LW Jr, Meeson BW, Fisher TR (1986) Phytoplankton production in two East coast estuaries: photosynthesislight functions and patterns of carbon assimilation in Chesapeake and Delaware Bays. Estuar Coast Shelf Sci 23:773-806

Horton T, Eichbaum W (1991) Turning the tide: saving the Chesapeake Bay. Chesapeake Bay Foundation, Island Press, New York

Houde ED, Rutherford ES (1993) Recent trends in estuarine fisheries: predictions of fish production and yield. Estuaries 16:161-176

Jordan TE, Correll DL, Miklas J, Weller DE (1991) Long-term trends in estuarine nutrients and chlorophyll and shortterm effects of variation in watershed discharge. Mar Ecol Prog Ser 75:121-132

Justic' D, Rabalais NN, Turner RE (1995) Stoichiometric nutrient balance and origin of coastal eutrophication. Mar Pollut Bull 30:41-46

Justic' D, Rabalais NN, Turner RE, Wiseman WJ Jr (1993) Seasonal coupling between riverborne nutrients, net productivity and hypoxia. Mar Pollut Bull 26:184-189

Kemp WM, Boynton WR (1984) Spatial and temporal coupling of nutrient inputs to estuartine production: the role of particulate transport and decomposition. Bull Mar Sci 35: $242-247$

Ljung GM, Box GEP (1978) On the measure of lack of fiot in time series models. Biometrika 65:297-303

Malone TC (1977) Environmental regulation of phytoplankton productivity in the lower Hudson estuary. Estuar Coast Shelf Sci 5:157-171

Malone TC (1992) Effects of water column processes on dissolved oxygen: nutrients, phytoplankton and zooplankton. In: Smith D. Leffler M, Mackiernan G (eds) Oxygen dynamics in Chesapeake Bay: a synthesis of research. University of Maryland Sea Grant College Publ, College Park, MD, p 61-112

Malone TC, Chervin M (1979) The production and fate of phytoplankton size fractions in the plume of the Hudson River, New York Bight. Limnol Oceanogr 24:683-696

Malone TC, Conley DJ, Fisher TR, Glibert PM, Harding LW, Sellner KG (1996) Scales of nutrient-limited phytoplankton productivity in Chesapeake Bay. Estuaries 19:371-385 
Malone TC, Crocker LH, Plke SE, Wendler BW (1988) Influences of river flow on the dynamics of phytoplankton production in a partially stratified estuary. Mar Ecol Prog Ser 48:235-249

Newcombe CL, Horne WA (1938) Oxygen-poor waters in the Chesapeake Bay. Science 88:80-81

Nixon SW, Oviatt CA, Frithsen J, Sullivan B (1986) Nutrients and the productivity of estuarine and coastal and marine ecosystems. J Limnol Soc South Afr 12:43-71

Nixon SW, Pilson MG (1983) Nitrogen in estuarine and coastal marine ecosystems. In: Carpenter EJ, Capone DG (eds) Nitrogen in the marine environment. Academic Press, New York, p 565-648

Officer CB, Biggs RB, Taft JL, Cronin LE, Tyler MA, Boynton WR (1984) Chesapeake Bay anoxia: origin, development, and significance. Science 223:22-27

Pennock JR (1985) Chlorophyll distributions in the Delaware estuary: regulation by light-limitation. Estuar Coast Shelf Sci 21:711-725

Pennock JR, Sharp JH (1986) Phytoplankton production in the

Editorial responsibility: Otto Kinne,

Oldendorf/Luhe, Germany
Delaware estuary; temporal and spatial variability. Mar Ecol Prog Ser 34:143-155

SAS Institute' Inc (1993) SAS/ETS user's guide, Version 6, 2nd edn. SAS Institute, Inc, Cary, NC

Seliger HH, Boggs JA, Buggley WH (1985) Catastrophic anoxia in the Chesapeake Bay in 1984. Science 228:70-73

Sharp JH, Cifuentes LA, Coffin RB, Pennock JR, Wong KC (1986) The influence of river variability on the circulation, chemistry, and microbiology of the Delaware estuary. Estuaries 9:261-269

Shumway RH (1988) Applied statistical time series analysis. Prentice Hall, Englewood Cliffs, NJ

Strickland JDH, Parsons TR (1968) A practical handbook of seawater analysis. Bull Fish Res Bd Can 167:1-311

Taft JL, Taylor WR, Hartwig EO, Loftus R (1980) Seasonal oxygen depletion in Chesapeake Bay. Estuaries 3:242-247

Turner RE, Rabalais NN (1991) Changes in Mississippi River water quality this century. BioScience 41:140-147

Turner RE, Rabalais NN (1994) Coastal eutrophication near the Mississippi river delta. Nature 368:619-621

Submitted: August 5, 1996; Accepted: July 25, 1997

Proofs received from author(s): September 29, 1997 